\title{
Two symbols, one solution
}

\author{
Saving a handful of photogenic species - or iconic rainforests - is no substitute for a comprehensive plan \\ that deals with climate, economics and the environment together.
}

\rceil he polar bear and the Amazon rainforest, two compelling symbols of the challenges presented by global warming, are again making headlines. For the polar bear, the news is that the United States has finally declared it to be a 'threatened' species as a result of climate-induced loss of sea ice (see page 432). The rainforest, meanwhile, has lost one of its most vocal champions with the resignation last week of Brazil's environment minister, Marina Silva.

Both the polar bear and the Amazon need all the protection they can get. But symbols, by themselves, are just that. What is at stake here is not a charismatic species of bear or one, admittedly vast, forest, but the livelihoods of everyone on Earth and the survival of biodiversity on a global scale.

In the case of the polar bear, US interior secretary Dirk Kempthorne deserves credit for approving the listing in the face of considerable pressure to do otherwise. Quite aside from the Bush administration's scepticism of regulation in general, the case for listing the polar bear was not exactly open-and-shut: international hunting restrictions have led to bear populations that are higher today than they have been in decades. Nonetheless, the scientific evidence for the threat was too strong to ignore.

Kempthorne's decision was delayed for months while the administration drew up regulations to prevent environmental activists using the 'threatened' designation in court to halt energy projects and shut down coal-fired power plants across the country. And the administration was correct to do so. The Endangered Species Act should not be used to sneak broad climate-policy decisions in through the back door. The proper place to make such decisions is openly, in Congress, where a debate on one major climate bill is already scheduled for early June.

In Brazil, meanwhile, where massive deforestation in the Amazon basin is adding its own burden of carbon dioxide to the atmosphere, Silva resigned her ministerial post citing difficulties in implementing federal environmental policy. Indeed, her tenure was marked

\section{Trials on trial}

\section{The Food and Drug Administration should rethink its rejection of the Declaration of Helsinki.}

ater this year, the US Food and Drug Administration (FDA) will adopt new standards for human clinical trials conducted without its advance sign-off in foreign countries. The rules will govern whether data from such trials can be used in applications to market the drug in question in the United States. Although these new standards specify how to run such trials to meet US requirements, they are worryingly silent on key issues relating to human rights, in by frequent disputes with pro-development forces both in industry and in her own government. The final straw may well have been the Brazilian government's new 'sustainable Amazon plan', which she is widely reported to have opposed. The plan would establish cheap loans to encourage better farming practices; increase aid and other social services for families who rely on logging; and set aside new conservation areas. More controversially, it would also provide for infrastructure such as new roads and hydroelectric dams.

Although Silva's resignation certainly raises questions about the viability of the government's scheme, Brazil's leaders are correct that the
"What is at stake here is not a charismatic species of bear or one, admittedly vast, forest, but the livelihoods of billions of people." Amazon needs some such comprehensive plan. It is condescending and counterproductive to say, as UK newspaper The Independent did recently, that the Amazon is too important to be left to the Brazilians. In fact, this region is home to some 25 million Brazilians who need to make a living, and it provides the hydroelectricity that powers much of Brazil's growing economy. Brazil has no choice but to manage it. Indeed, President Luiz Inácio Lula da Silva has promised that his efforts to halt deforestation will continue under the new environment minister, Carlos Minc. A co-founder of the Green Party in Brazil, Minc most recently served as the top environmental regulator for the state of Rio de Janeiro.

The world will be watching to see how this plays out. In the meantime, those concerned about the Amazon - and the polar bear should keep their focus on the real long-term solution: establishing comprehensive climate-regulatory regimes and providing carbonfree energy sources. If all goes well, tomorrow's industrialists might one day discover that it is profitable to reduce emissions by funding conservation programmes in the Amazon. In doing so, they might even help the polar bear.

contrast with the rules currently in effect. As a result, they could open the way to some ethically fraught decisions.

Take the case of the drug Surfaxin, a synthetic, inhaled version of a lung protein the absence of which is a leading cause of death in premature infants. Back in 2001, the drug's manufacturer, Discovery Labs of Warrington, Pennsylvania, was looking for a suitable location in Latin America to run a trial on the therapy. But rather than compare its product to one of the several effective drugs already available, Discovery Labs was proposing to administer a placebo to the 325 infants in the control group.

The trial was redesigned only after the FDA — and unfavourable media attention - reminded Discovery Labs that a placebo-controlled trial of this type would be deemed unethical in the United States, 